\title{
Secondary organic aerosol from biogenic VOCs over West Africa during AMMA
}

\author{
G. Capes ${ }^{1}$, J. G. Murphy ${ }^{2, *}$, C. E. Reeves ${ }^{2}$, J. B. McQuaid ${ }^{3}$, J. F. Hamilton ${ }^{4}$, J. R. Hopkins ${ }^{4}$, J. Crosier ${ }^{1}$, \\ P. I. Williams ${ }^{1}$, and H. Coe ${ }^{1}$ \\ ${ }^{1}$ Centre For Atmospheric Science, S. E. A. E. S., University Of Manchester, UK \\ ${ }^{2}$ School of Environmental Sciences, University of East Anglia, Norwich, UK \\ ${ }^{3}$ Institute for Climate and Atmospheric Science, S. E. E., University of Leeds, Leeds, UK \\ ${ }^{4}$ Department of Chemistry, University of York, York, N. Yorkshire, UK \\ *now at: University of Toronto, Canada
}

Received: 13 October 2008 - Published in Atmos. Chem. Phys. Discuss.: 27 January 2009

Revised: 28 April 2009 - Accepted: 26 May 2009 - Published: 15 June 2009

\begin{abstract}
This paper presents measurements of organic aerosols above subtropical West Africa during the wet season using data from the UK Facility for Airborne Atmospheric Measurements (FAAM) aircraft. Measurements of biogenic volatile organic compounds (BVOC) at low altitudes over these subtropical forests were made during the African Monsoon Multidisciplinary Analysis (AMMA) field experiment during July and August 2006 mainly above Benin, Nigeria and Niger. Data from an Aerodyne Quadrupole Aerosol Mass Spectrometer show a median organic aerosol loading of $1.07 \mu \mathrm{g} \mathrm{m}^{-3}$ over tropical West Africa, which represents the first regionally averaged assessment of organic aerosol mass $(\mathrm{OM})$ in this region during the wet season. This is broadly in agreement with global model predictions based on partitioning schemes, although there are large uncertainties associated with such estimates. In contrast our own calculations based on aerosol yields from isoprene and monoterpenes during chamber studies under represent the OM measured in this region on a comparable scale to the under representations of OM by predictive models in the mid latitudes. As global models rely on similar yield calculations in their global estimates, as our calculations this points to further systematic differences between global model estimates and measurements of SOA, most likely caused by use of incorrect $\mathrm{BVOC}$ emission rates. The under predictions of $\mathrm{OM}$ by our calculations and those in the mid latitudes employ yields
\end{abstract}

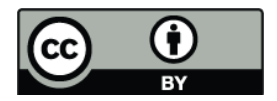

Correspondence to: G. Capes (gerard.capes@manchester.ac.uk) extrapolated from chamber data obtained at higher mass concentrations - more recent yield data for $\alpha$-pinene obtained at ambient concentrations in a flow through chamber (Shilling et al., 2008) show considerably better agreement with our data.

\section{Introduction}

Atmospheric aerosols play a key role in climate and atmospheric chemistry. The composition of atmospheric aerosols worldwide is often dominated by the organic fraction (Zhang et al., 2007; Andreae and Crutzen, 1997) and in many cases, the organic aerosol mass is dominated by secondary material (Kanakidou et al., 2005; Volkamer et al., 2006). Measurements of organic aerosol from anthropogenic pollution are widespread in the Northern Hemisphere, whereas measurements in pristine tropical environments and in particular large areas of Africa remain less well represented in the literature.

Current models based on gas/aerosol partitioning schemes systematically underestimate the measured organic aerosol mass loading in continental northern mid-latitudes (Chung and Seinfeld, 2002; Heald et al., 2005; Johnson et al., 2006; De Gouw et al., 2005) and the discrepancy between modelled and measured values increases with photochemical age (Volkamer et al., 2006); this underestimation highlights our limited understanding of secondary organic aerosol (SOA) formation (and loss) processes. Biogenic volatile organic compounds (BVOCs) are thought to be emitted in greater quantities than anthropogenic VOC emissions on a global

Published by Copernicus Publications on behalf of the European Geosciences Union. 
basis (Guenther et al., 2000, 1995), so the formation potential for biogenic secondary organic aerosol (BSOA) is substantial (Kavouras et al., 1998), particularly in the tropics where biogenic emissions (Guenther et al., 1995) and concentrations of hydroxyl radicals $(\mathrm{OH})$ (Spivakovsky et al., 1990) are at a maximum. Organic aerosols can exert a direct radiative effect by scattering and absorbing solar and terrestrial radiation but also indirect radiative effects, through their role as cloud condensation nuclei (CCN). Furthermore, predicting human influence on aerosol radiative effects is dependent on quantifying the natural particle system; therefore an inability to predict the quantity and spatial distribution of naturally produced organic particulate matter has important climatic implications.

The UK BAe-146 research aircraft, operated by the Facility for Airborne Atmospheric Measurements (FAAM), was based at Niamey airport in Niger $\left(2.17^{\circ} \mathrm{E}, 13.48^{\circ} \mathrm{N}\right)$ between 17 July 2006 and 17 August 2006 to coincide with the onset of the wet season as part of the African Monsoon Multidisciplinary Analysis (AMMA) programme. We show here data from 17 of the 24 sorties flown which give good coverage along a north-south transect between the semi-arid Niamey region of southern Niger and large areas of tropical forest in Benin at low altitudes. Not all instruments were operating on all flights; hence we only consider here those flights where all relevant data is available. During the monsoon season, the prevailing low level $(925 \mathrm{hPa})$ wind direction was south westerly (Janicot et al., 2008), blowing from the Gulf of Guinea over the forested regions of Benin towards Niamey in the north of the operating region. A very clean aerosol background was observed across the region and organic aerosols were detected over forested regions. It should be noted that most of the region is quite rural and there are no major anthropogenic fossil fuel pollution sources. This study compares the regional mass loading with modelling estimates and measured yields from chamber experiments. We present here a regionally averaged mass loading for organic aerosol over West Africa during the 2006 wet season; to our knowledge this is the first time such a measurement has been performed.

\section{Aircraft instrumentation}

Data was collected on a modified BAe-146 aircraft, which contains a range of instruments to measure aerosol number and composition, trace gas concentrations, and standard meteorological variables.

An Aerodyne Research Inc. Quadrupole Aerosol Mass Spectrometer (Q-AMS) was used to provide near real time mass loadings and chemical composition of the nonrefractory components of submicron aerosols. The instrument samples aerosol into a vacuum through an aerodynamic lens, which focuses the particles at a heated vaporizer, where they volatilise. The gas plume is ionised using electron ionisation at $70 \mathrm{eV}$ and the ion fragments are analysed using a quadrupole mass filter and electron multiplier. The QAMS has been described thoroughly in previous publications (Jayne et al., 2000; Jimenez et al., 2003; Allan et al., 2003) and the particular aircraft installation of the Q-AMS on the BAe-146 is described in detail by Crosier et al. (2007). The thermal vaporizer is maintained at $\sim 600^{\circ} \mathrm{C}$, so the Q-AMS is insensitive to refractory components such as black carbon and mineral dust, which do not vaporize at this temperature. The Q-AMS was calibrated for mass quantification (Ionisation Efficiency, IE) pre- and post-flight using the method of Jimenez et al. (2003) and error estimates are made following the procedure of Allan et al. (2003). The particle beam is blocked every few seconds to measure the signal due to the background in the instrument and this is subtracted from the sample signal. Instrument noise can therefore be estimated by placing a particle filter in the sample inlet. Such estimates during AMMA show the noise for a $30 \mathrm{~s}$ sample to be around $3.3 \mu \mathrm{g} \mathrm{m}^{-3}$ for organics at an altitude of $600 \mathrm{~m}$. All Q-AMS data (including the above uncertainty estimate) are reported in mass concentrations at standard temperature and pressure $(273.15 \mathrm{~K}, 101.325 \mathrm{kPa})$.

Previous studies (e.g. Canagaratna et al., 2007, and studies therein) have shown that when particles are solid a significant number may bounce off the heater, reducing the collection efficiency (CE) below unity. The CE is often evaluated by comparison with other instruments such as PILS-IC or filter measurements and has been shown to be around 0.42 for sulphate aerosol (Drewnick et al., 2005). Particle phase plays a central role in the CE: liquid particles are sampled with a $\mathrm{CE}$ of 1 yet the vast majority of ambient measurements from a range of different environments are well characterised by CEs between 40-50\% (Matthew et al., 2008). For pure biogenic SOA, where the particles tend to be liquid aerosols, the CE tends to $100 \%$ (Alfarra, 2004). However, sulphate mass loadings over the region were comparable to those of organics, and in previous locations where the sulphate and organics loadings were approximately 50:50 the CE has been shown to be around 0.5 (Zhang et al., 2005). The aerosols during AMMA were bulk neutralized within the uncertainties of the measurements (see method of Zhang et al., 2005) and this tends to be associated with a CE around 0.5 (Allan et al., 2004). In this study it was not possible to directly evaluate the true $\mathrm{CE}$ by comparison with other instruments, and for the reasons discussed above a CE of 0.5 has been used for the data shown.

Measurements of a suite of volatile organic compounds were made by proton transfer reaction mass spectrometry (PTR-MS; Ionicon Analytik). Specific masses corresponding to protonated species of interest were measured for one second every $10-15 \mathrm{~s}$. Zeros were carried out periodically in-flight by diverting the sample air stream through a custom built stainless steel tube filled with a platinum-coated quartz wool catalyst (Shimadzu) heated to $400^{\circ} \mathrm{C}$. The response of the PTR-MS was calibrated pre- and post-campaign using a multi-component standard (Apel-Riemer). Due to the 
high absolute humidity encountered during the flights, the protonation of VOCs by both $\mathrm{H}_{3} \mathrm{O}^{+}$and the water cluster, $\mathrm{H}_{3} \mathrm{O}^{+} \mathrm{H}_{2} \mathrm{O}$, was taken into account. Isoprene is assumed to be the major contribution to the signal at mass to charge ratio $(\mathrm{m} / \mathrm{z}) 69$, thus the accuracy of this measurement is similar to that quoted for the standard (5\%). Both methylvinyl ketone (MVK) and methacrolein (MACR) contribute to the signal at $m / z 71$, so strictly speaking it would be necessary to know the sensitivity and relative contribution of each to calculate the sum of their concentrations. Because we have no alternate measurement of their individual concentrations, the accuracy of the reported sum of their concentrations at $\mathrm{m} / \mathrm{z} 71$ depends on the similarity of their sensitivities. Individual permeation tubes (Eco-scientific) were used to measure their independent responses, which showed them to be within $20 \%$ of each other, thus a conservative estimate of the total uncertainty of the reported sum (MVK+MACR) is $25 \%$.

Whole air samples (WAS) were collected in silica coated stainless steel canisters (Thames Restek, UK) for off-line analysis of $\left(\mathrm{C}_{2}-\mathrm{C}_{8}\right)$ Volatile Organic Compounds (VOCs). Air samples were analysed using a dual channel gas chromatograph with flame ionisation detectors (Hopkins et al., 2003).

A number of higher molecular weight gas phase volatile organic compounds including monoterpenes were collected using carbon based adsorbent tubes filled with Carbopack B, Carbopack C and Carbosieve SIII (Supelco, Bellefonte, PA, USA). Ambient air was drawn from the portside aircraft air sample pipe which is located towards the front of the aircraft extending beyond the skin boundary layer. A stainless steel metal bellows pump (Metal Bellows, USA) was used to generate a positive pressure system as this ensures that any potential leaks in the sampling train do not compromise the integrity of the sample.

Speciated analysis was accomplished using a GC-TOFMS system (Gas Chromatography coupled to Time Of Flight Mass Spectrometry) comprising an HP 6890 (Agilent Technologies, USA) gas chromatograph and a Pegasus III TOFMS (LECO, St. Joseph, MI, USA) which is based in the analytical research laboratory at the University of York. The analytical column was a non-polar methyl polysiloxane DB5 type $(60 \mathrm{~m} \times 0.25 \mathrm{~mm}$ i.d. $\times 1 \mu \mathrm{m}$ film thickness $)$ from $\mathrm{J} \& \mathrm{~W}$ Scientific (Folsom, CA, USA). A detailed description of the analytical system and operation parameters can be found in (Saxton et al., 2007). Quantification was possible for 4 monoterpenes; $\alpha$-pinene, limonene, $\beta$-pinene and camphene. Several other monoterpenes were observed but without good standards it was not possible to provide quantitative data for them and thus they were not reported here. Unsampled tubes were kept as field blanks to measure contamination during handling. Backgrounds ranged from less than 20 to $30 \mathrm{pptV}$ for the instrument to a maximum of 25 to $150 \mathrm{pptV}$ for an uncapped handling blank. Based on measurements of the gas standards, the precision was estimated to be 22 to $34 \%$ (Coefficient of Variation) and accuracy $20 \%$.
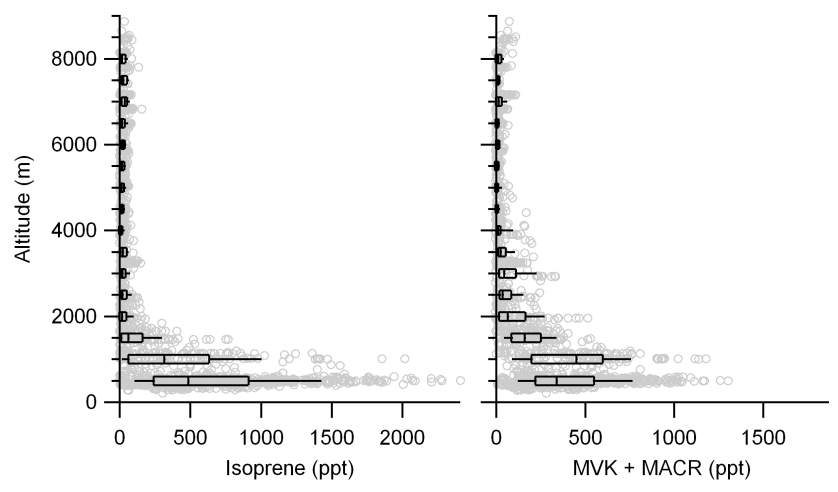

Fig. 1. Vertical profiles show isoprene and its degradation products methyl vinyl ketone (MVK) and methacrolein (MACR) between $7-13^{\circ} \mathrm{N}$. Grey markers are individual data points. The box and whiskers show concentrations at $500 \mathrm{~m}$ intervals, at the mid point of each $500 \mathrm{~m}$ altitude bin. The box centre denotes the median concentration; box edges denote the upper and lower quartiles; whisker extremities denote the 10th and 90th percentile concentrations.

\section{Results}

The measurements made at low altitude over forested areas revealed a strong correlation between VOC concentrations and vegetation density. Isoprene has an atmospheric lifetime of around $1.75 \mathrm{~h}$ during the daytime in the mean conditions experienced during AMMA $\left(24 \mathrm{ppb} \mathrm{O}_{3}, 1.5 \times 10^{6} \mathrm{~cm}^{-3}\right.$ $\mathrm{OH})$, so its spatial distribution on these scales can be used as an indicator of local vegetative emissions. BVOCs such as monoterpenes and isoprene are known precursors for SOA formation (Claeys et al., 2004; Kavouras et al., 2000) and it is where BVOC concentrations are high that SOA formation is most likely.

Isoprene is emitted in high concentrations from many species of vegetation in tropical regions (Kuhn et al., 2002). During the field project high concentrations of isoprene and its oxidation products methacrolein (MACR) and methyl vinyl ketone (MVK) were found at altitudes below $2000 \mathrm{~m}$ over forested regions (e.g. concentrations up to $2 \mathrm{ppb}$ of isoprene were recorded at $500 \mathrm{~m}$ altitude - see Fig. 1 for vertical profiles). It is known that different plant types have widely varying emission rates of isoprene and monoterpenes and their relative emission rates can also be highly variable from species to species (Otter et al., 2002; Guenther et al., 1996; Greenberg et al., 2004). Given that this region has a very varied range of plant species (Guenther et al., 1996; Saxton et al., 2007; Greenberg et al., 2004) there will inevitably be a significant amount of spatial averaging of the emission profiles from individual species when measured from an airborne platform. The mean $\alpha$-pinene concentration at altitude $<2000 \mathrm{~m}$ over the forested regions was $38 \mathrm{ppt}$; the mean for isoprene was $610 \mathrm{ppt}$. The $\alpha$-pinene concentration will be an overestimate relative to isoprene because the tube samples were collected specifically when high VOC concentrations 


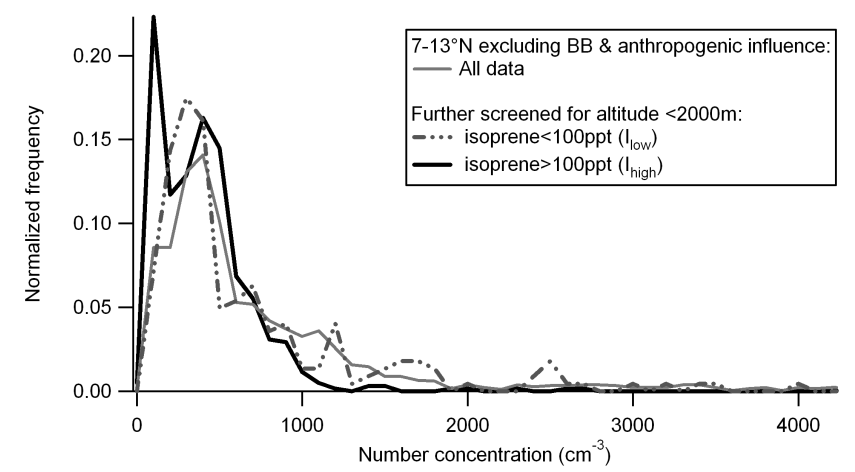

Fig. 2. Frequency distribution for particle number concentration, shown for all data between 7 and $13^{\circ} \mathrm{N}$ excluding periods of biomass burning and anthropogenic influences and data further screened according to altitude and isoprene concentrations.

were expected, compared to the continuous sampling of the PTR-MS and Q-AMS.

Typical aerosol number concentrations in the region were low (particle number concentration greater than $3 \mathrm{~nm}$ $<500 \mathrm{~cm}^{-3}$ ) which indicates a very clean background (Fig. 2). Number concentrations shown have been screened to remove influence from other sources such as biomass burning and large urban centres. Biomass burning influence was identified by enhancement in acetonitrile concentration, whereas the only major urban plume sampled by the aircraft (Lagos) was identified geographically and by enhanced CO concentrations. The data were further screened to investigate the change in number concentration in air sampled with high or low concentrations of isoprene, using a threshold of $100 \mathrm{ppt}$ (subsequently referred to as the $I_{\text {high }}$ and $I_{\text {low }}$ subsets). The $I_{\text {high }}$ screening criteria used are intended to reveal the biogenic signature over the forest, whereas the $I_{\text {low }}$ air represents more aged regional air. Typical number concentrations for the $I_{\text {high }}$ and $I_{\text {low }}$ subsets are very similar - less than $500 \mathrm{~cm}^{-3}$ in each case.

In forested regions in mid and high latitudes, an order of magnitude enhancement in the number concentration over background values has been observed during nucleation events with particle concentrations around $10^{4} \mathrm{~cm}^{-3}$ (Kulmala et al., 2001); this was not evident during AMMA as can be seen in Fig. 2. This lack of new particle formation is in agreement with that previously observed from a ground station in the Amazon (Zhou et al., 2002; Rissler et al., 2004).

Low loadings of aerosol particle mass were observed throughout the whole region when the data were screened to remove the occasional influences of biomass burning and urban pollution. For this reason, mass loadings during AMMA have been determined on the basis of statistical comparison. Highest concentrations of BVOCs were observed at altitudes below $2000 \mathrm{~m}$ (see Fig. 1) and the Q-AMS has improved signal-to-noise when the sample pressure is high (Crosier et al., 2007), so only data points below $2000 \mathrm{~m}$ were se- lected for this estimate. Further data selection employs the same criteria as described to investigate the number concentration. Figure 3 shows organic mass frequency distributions for $I_{\text {high }}$ and $I_{\text {low }}$ periods; the mean, lower quartile, median, upper quartile and standard deviations of these distributions are summarised in Table 1. This analysis shows an enhancement in OM for the air with elevated isoprene concentrations, which would tend to indicate BSOA formation, though the enhancement is small.

Many of the data points in the $I_{\text {high }}$ subset also exhibited elevated mean benzene concentrations ( $96 \mathrm{ppt}$ compared with $76 \mathrm{ppt}$ for the $I_{\text {low }}$ data), which is indicative of anthropogenic pollution sources (e.g. Fenger, 1999). Benzene is a much longer lived VOC than isoprene and so may have been transported considerable distance from its source. It is therefore possible that the observed OM has a contribution from dilute anthropogenic pollution - cf. benzene concentrations of 1-2 ppb in polluted environments (Rappengluck et al., 2000; Steinbacher et al., 2005). However, it has been observed that toluene is emitted from some vegetation (White et al., 2009) and it may be that similar emissions contribute to the small enhancement in benzene observed. Sulphate aerosols were observed in the $I_{\text {high }}$ subset i.e. in the same region as enhanced OM (see Fig. 4). However, similar concentrations of sulphate were present throughout the whole dataset and moreover the presence of sulphate is inconclusive as an indicator of anthropogenic influence. A major source of sulphate aerosols is $\mathrm{SO}_{2}$ from anthropogenic activity, but there are also biogenic sources, which may be significant in this region; the observed mass concentrations are consistent with aerosol formation from vegetative emissions of dimethylsulphide (DMS) and $\mathrm{H}_{2} \mathrm{~S}$ (Andreae et al., 1990).

With the notable exception of isoprene, the WAS data show low VOC concentrations in both the $I_{\text {high }}$ and $I_{\text {low }}$ air, compared with regions containing large anthropogenic sources e.g. typical rural UK values are a factor of 2-10 higher (Fowler et al., 1997); species such as ethane and propane dominate the VOC signature over West Africa which indicates very aged air. This is consistent with the very low $\mathrm{NO}_{\mathrm{x}}$ concentrations over the region (median $0.21 \mathrm{ppb}$, interquartile range $0.31 \mathrm{ppb}$ for $I_{\text {high }}$ ). Hence, while it is most likely that the $\mathrm{OM}$ in this study is dominated by the biogenic contribution, some contribution from anthropogenic sources cannot be entirely ruled out. These data therefore represent an upper limit to the biogenically produced SOA loading.

\section{Theoretical SOA estimates for West Africa}

Isoprene, monoterpenes and sequiterpenes are thought to be the major SOA precursors globally (Kroll et al., 2006; Kanakidou et al., 2005) so an estimate for SOA formation should be based on these compound classes. Isoprene and monoterpenes have been shown to be emitted from forested regions of the African Sahel in high concentrations during 
Table 1. Organic mass loadings $\left(\mu \mathrm{g} \mathrm{m}^{-3}\right)$ for data screened for various criteria. $I_{\text {high }}$ and $I_{\text {low }}$ indicate data below $2000 \mathrm{~m}$ (excluding urban centres, biomass burning influences and data outside the latitude range $7-13^{\circ} \mathrm{N}$ ), selected for isoprene above and below $2000 \mathrm{~m}$. Q1 and Q3 are the lower and upper quartiles. The mean is quoted \pm standard error.

\begin{tabular}{lcrrrr}
\hline Criteria & Mean \pm std err & Median & Q1 & Q3 & Standard deviation \\
\hline All data & $0.216 \pm 0.096$ & 0.0310 & -1.786 & 1.564 & 6.36 \\
All $<2000 \mathrm{~m}$ & $1.18 \pm 0.16$ & 0.614 & -0.642 & 1.90 & 8.06 \\
$I_{\text {low }}$ & $0.520 \pm 0.112$ & 0.480 & -0.696 & 1.626 & 1.804 \\
$I_{\text {high }}$ & $1.164 \pm 0.062$ & 1.072 & 0.125 & 2.14 & 1.762 \\
\hline
\end{tabular}

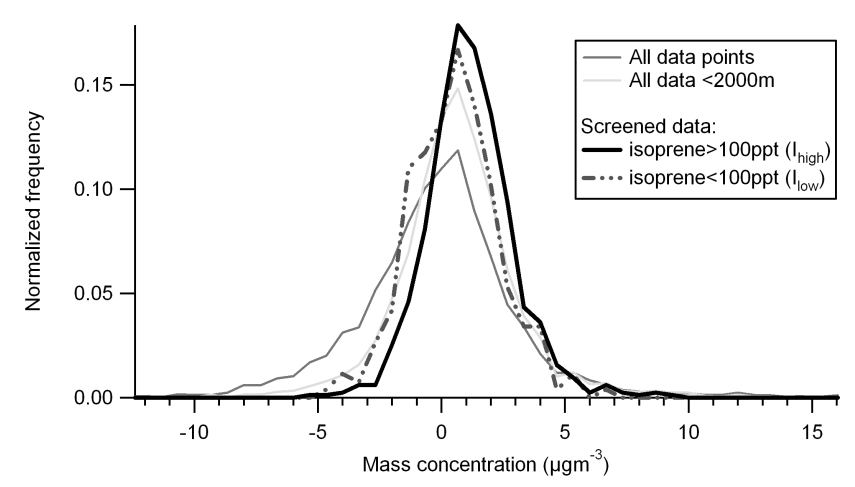

Fig. 3. Frequency distributions for organic aerosol mass. The screened data is below $2000 \mathrm{~m}$ and excludes urban centres and biomass burning influences and data outside the latitude range $7-$ $13^{\circ} \mathrm{N}$.

the wet season (Saxton et al., 2007), but no quantitative measurements for sesquiterpenes are available. Our estimate is therefore based on isoprene and monoterpenes only and hence is likely to be an under prediction. However, neglect of lower volatility, high-yield SOA precursors when predicting SOA formation is a general issue and is not unique to biogenically-influenced areas. For example the oxidation of large ( $\mathrm{C}_{15}$ and higher) alkanes is not included in most models but these reactions form SOA very efficiently (Robinson et al., 2007; Lim and Ziemann, 2005). A simple approach to estimating the SOA formation from the observed isoprene and monoterpenes is presented using data from the regions defined by the $I_{\text {high }}$ screening criteria outlined for Fig. 3 . This subset is used for the calculation, in order that a direct comparison can be made with the SOA measurements. Isoprene, $\alpha$-pinene, $\beta$-pinene and limonene were the precursor species measured for which relevant emission ratios were readily available.

Chamber estimates of isoprene derived SOA suggest mass yields around 1\% (Kroll et al., 2006), and molar yields of MVK and MACR from isoprene oxidation have been shown to be $15 \%$ and $18 \%$, respectively, in low $\mathrm{NO}_{\mathrm{x}}$ conditions (Ruppert and Becker, 2000). Assuming that the only source of MVK and MACR is isoprene degradation, and that

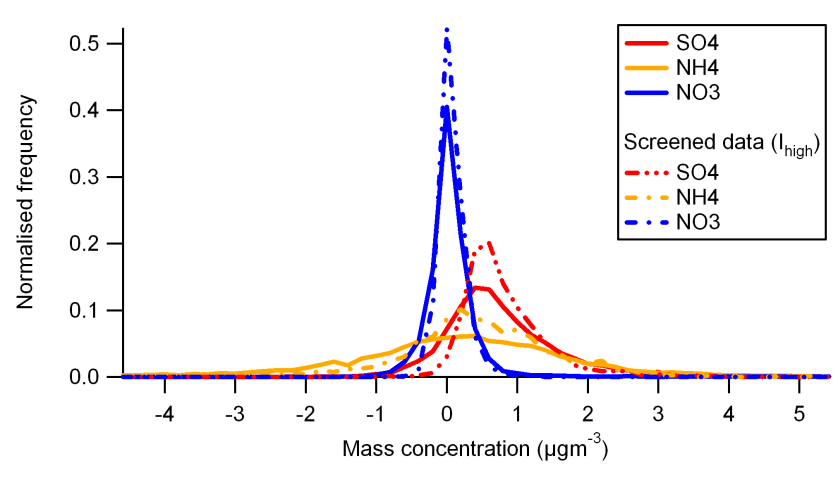

Fig. 4. Frequency distributions for inorganic aerosol mass. "Screened" data refers to data below $2000 \mathrm{~m}$ with isoprene $>100 \mathrm{ppt}$, excluding urban centres, biomass burning influences and data outside the latitude range $7-13^{\circ} \mathrm{N}$.

MVK+MACR are not themselves oxidised appreciably on the timescales relevant to this analysis, the measured MVK and MACR concentrations indicate the total amount of isoprene oxidised (Eq. 1), which can then be used to predict the concentration of SOA formed (Eq. 2).

$$
\begin{aligned}
& {[\mathrm{Iso}]=\frac{[\mathrm{MVK}+\mathrm{MACR}]}{Y_{\mathrm{MVK}}+Y_{\mathrm{MACR}}}} \\
& \mathrm{SOA}_{\mathrm{Iso}}=[\mathrm{Iso}] \times Y_{\mathrm{SOA}}=\frac{[\mathrm{MVK}+\mathrm{MACR}]}{Y_{\mathrm{MVK}}+Y_{\mathrm{MACR}}} \times Y_{\mathrm{SOA}}
\end{aligned}
$$

Converting the units in Eq. (2) from molar to mass yields and mixing ratios to mass concentrations yields an estimate for SOA mass concentration given by Eq. (3).

$$
\begin{aligned}
\mathrm{SOA}_{\mathrm{Iso}}= & {[\mathrm{MVK}+\mathrm{MACR}] } \\
& \times \frac{Y_{\mathrm{SOA}}}{Y_{\mathrm{MVK}}\left(\frac{M_{\mathrm{MVK}}}{M_{\mathrm{Iso}}}\right)+Y_{\mathrm{MACR}}\left(\frac{M_{\mathrm{MACR}}}{M_{\mathrm{ISO}}}\right)} \\
& \times n \times \frac{M_{\mathrm{MVK}+\mathrm{MACR}}}{N_{A}}
\end{aligned}
$$

Where $\mathrm{SOA}_{\text {Iso }}=\mathrm{SOA}$ mass concentration from isoprene oxidation, $[\mathrm{MVK}+\mathrm{MACR}]=$ concentration of the sum of MVK and MACR (ppt), $Y_{\mathrm{SOA}}=$ aerosol mass yield $=0.01(\mathrm{Kroll}$ et al., 2006), $Y_{\mathrm{MVK}}=$ molar yield of $\mathrm{MVK}=0.15$ (Ruppert 
and Becker, 2000), $Y_{\mathrm{MACR}}=$ molar yield of $\mathrm{MACR}=0.18$ (Ruppert and Becker, 2000), $n=$ number of molecules in $1 \mathrm{~m}^{3}$ air $=2.5 \times 10^{25}, N_{A}=$ Avogadro's number $=6.02 \times 10^{23}$, $M_{\text {Iso }}=$ molar mass of isoprene $=68 \mathrm{gmol}^{-1}, M_{\mathrm{MVK}}=$ molar mass of $\mathrm{MVK}=70 \mathrm{gmol}^{-1}, \quad M_{\mathrm{MACR}}=$ molar mass of $\mathrm{MACR}=70 \mathrm{gmol}^{-1}, M_{\mathrm{MVK}+\mathrm{MACR}}=$ molar mass of $\mathrm{MVK}$ and $\mathrm{MACR}=70 \mathrm{gmol}^{-1}$. The median MVK+MACR concentration for the $I_{\text {high }}$ subset was observed to be $380 \mathrm{ppt}$. Equation (3) gives a prediction of organic mass loading from isoprene degradation of $0.0597 \pm 0.033 \mu \mathrm{g} \mathrm{m}^{-3}$ over the region. The uncertainty quoted is the standard deviation and reflects variability in the MVK+MACR concentration; the choice of $Y_{\mathrm{SOA}}$ reflects the low $\mathrm{NO}_{\mathrm{x}}$ concentrations and low overall mass concentrations.

This estimate assumes complete oxidation of isoprene to achieve the final concentration of SOA. Certainly, the methylvinyl ketone and methacrolein concentrations in Fig. 1 are similar in magnitude to that of isoprene, indicating that considerable oxidation has taken place, and the mixing time in the atmosphere is of the order of several hours. The lifetime of MVK + MACR is around $8 \mathrm{~h}$ (Atkinson et al., 2006), so there is decay on the time scale of a day. Chamber measurements indicate that SOA formation is complete $6-10 \mathrm{~h}$ after the start of oxidation (Kroll et al., 2006; Dommen et al., 2006), so the approach we have taken should give a reasonable estimate of SOA from isoprene oxidation for the first $8 \mathrm{~h}$ or so before oxidation of MVK+MACR starts to appreciably reduce their concentrations and lead to an underestimate of total isoprene emitted (Eq. 1). During the West African Monsoon (WAM), the predominant wind direction at the surface is south-westerly (Parker et al., 2005b) and so air in this region originates largely from the Gulf of Guinea. Large tropical storms (termed Mesoscale Convective Systems - MCSs) passed through the operating region every few days, so there would have been removal of BVOCs from the region by large scale convection every 2-4 days. Smaller scale daily convection and associated vertical mixing (Parker et al., 2005a) means that it is unlikely we sampled air masses of chemical age much longer than one day. If significant loss of MVK+MACR were to be occurring, this would under represent the total isoprene emitted and hence underestimate the SOA predicted. Our prediction may therefore underestimate formation of SOA to an extent.

An estimate of the contribution of monoterpenes to the SOA can be derived by extending the approach above. Monoterpenes, like isoprene are short lived in the atmosphere whereas aerosols are long lived, and hence their contribution to the measured SOA is due to the integrated amount of monoterpene emitted into the air mass and is nearly independent of the in situ abundance of the BVOC. Hence we assume that the total quantity of a particular VOC that has reacted to form products (denoted by the subscript TR) arises from the total quantity of the VOC emitted (denoted by the subscript TE) see Eq. (4). Using an $\alpha$-pinene (AP)/ isoprene (Iso) emission ratio (by mass) of $1.0 \pm 0.1$ to repre- sent $\mathrm{AP}_{T E} / \mathrm{Iso}_{T E}$ (derived from ground based measurements in Benin during the same time period as our measurements Saxton et al., 2007), and using a suitable aerosol yield from $\alpha$-pinene, $Y_{A P}=0.01$ (extrapolated from Griffin et al., 1999a), we arrive at an estimate for SOA from $\alpha$-pinene expressed by Eq. (5), $\operatorname{SOA}_{A P}=0.0608 \pm 0.0406 \mu \mathrm{g} \mathrm{m}^{-3}$.

$$
\begin{aligned}
& A P_{T R}=\mathrm{Iso}_{T R} \times \frac{A P_{T E}}{\mathrm{Iso}_{T E}} \\
& \mathrm{SOA}_{\mathrm{ISO}}=\frac{\mathrm{SOA}_{\text {Iso }}}{Y_{\text {Iso }}} \frac{A P_{T E}}{\mathrm{IsO}_{T E}} Y_{A P}
\end{aligned}
$$

The same approach was taken for $\beta$-pinene (BP) and limonene using emission ratios $\mathrm{BP} / \mathrm{Iso}=1.0 \pm 0.1$, Limonene/Iso $=2 \pm 0.2$ (Saxton et al., 2007) and yields $Y_{B P}=0.034, Y_{\text {Limonene }}=0.082$ (extrapolated from Griffin et al., 1999a) to give $\operatorname{SOA}_{B P}=0.0202 \pm 0.0132 \mu \mathrm{g} \mathrm{m}^{-3}$, and $\mathrm{SOA}_{\text {limonene }}=0.098 \pm 0.062 \mu \mathrm{g} \mathrm{m}^{-3}$. Uncertainties in these estimates reflect the uncertainty in the emission ratios used,

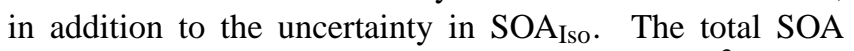
predicted from this calculation is $0.24 \pm 0.15 \mu \mathrm{g} \mathrm{m}^{-3}$.

For comparison, a range of SOA estimates have been generated in this manner using emissions data from studies in tropical forests in South America. These reflect the high degree of variability in emission profiles between different locations with similar biome and are summarized in Table 2 . However, measurements taken in Amazonia may not be representative of BVOC in West Africa; indeed there is significant variability in emission characteristics even between (the large variety of) plant species present in West Africa (Guenther et al., 1996; Otter et al., 2002; Saxton et al., 2007). Given that the 1/e lifetimes of $\alpha$-pinene and isoprene under conditions experienced during AMMA were both around $2 \mathrm{~h}$ (2.08 and $1.75 \mathrm{~h}$, respectively), the $\alpha$-pinene/isoprene emission ratio should be similar to the ambient ratio measured on the aircraft. However, all the monoterpene/isoprene ratios from the aircraft were an order of magnitude lower than those from the ground site in Benin (i.e. Saxton et al., 2007), which cannot be accounted for by differing atmospheric lifetimes relative to isoprene. It may be that the ground based measurements are not representative of the wider West African region due to the inhomogeneity of plant species; this discrepancy could alternatively arise from a sampling bias in either the aircraft or ground based measurements; or it may simply be indicative of the inherent uncertainty associated with the relatively small number of data points available from this type of sampling from an airborne platform. The range of total SOA predicted by these estimates based on isoprene and the three monoterpenes is $0.07-0.24 \mu \mathrm{g} \mathrm{m}^{-3}$, which corresponds to an under prediction of the measured OA by a factor of 4.515.

Our estimate based on four precursor species should account for a significant fraction of the total SOA formation potential from BVOC e.g. $\alpha$-pinene, $\beta$-pinene and limonene 
Table 2. SOA estimates $\left(\mu \mathrm{g} \mathrm{m}^{-3}\right)$ from Eqs. (2) and (5) using a range of emission ratios (ER). AMMA tubes refers to ambient concentrations from the adsorbent tubes, though isoprene and $\alpha$-pinene have very similar 1/e lifetimes under the conditions during AMMA (1.75 $\mathrm{h}$ and $2.08 \mathrm{~h}$ respectively) and so the ratio of their concentrations should remain approximately constant from source; the other tubes ratios give an order of magnitude estimate. $\mathrm{SOA}_{\text {total }}$ is the total SOA predicted using each emission ratio/yield combination and includes the contribution from isoprene, $\mathrm{SOA}_{\mathrm{Iso}}=0.0597 \pm 0.0328 \mu \mathrm{g} \mathrm{m}^{-3}$.

\begin{tabular}{lcccc}
\hline & Saxton et al. (2007) & AMMA Tubes & Kesselmeier et al. (2000) & Greenberg et al. (2004) \\
\hline $\mathrm{ER}_{\alpha \text {-pinene/isoprene }}$ & $1.0 \pm 0.1$ & $0.1008 \pm 0.108$ & $1.14 \pm 0.56$ & $0.22 \pm 0.058$ \\
$\mathrm{ER}_{\beta \text {-pinene/isoprene }}$ & $1.0 \pm 0.1$ & $0.0504 \pm 0.124$ & $0.34 \pm 0.18$ & $\mathrm{n} / \mathrm{a}$ \\
$\mathrm{ER}_{\text {Limonene/isoprene }}$ & $2.0 \pm 0.2$ & $0.0956 \pm 0.105$ & $0.22 \pm 1.10$ & $\mathrm{n} / \mathrm{a}$ \\
& & & & \\
$\mathrm{SOA}_{\alpha \text {-pinene }}^{\mathrm{a}}$ & $0.0607 \pm 0.0395$ & $0.00612 \pm 0.0065$ & $0.0692 \pm 0.0340$ & $0.0134 \pm 0.0035$ \\
$\mathrm{SOA}_{\beta \text {-pinene }}^{\mathrm{a}}$ & $0.0201 \pm 0.0131$ & $0.00101 \pm 0.0025$ & $0.0068 \pm 0.0036$ & $\mathrm{n} / \mathrm{a}$ \\
$\mathrm{SOA}_{\text {Limonene }}^{\mathrm{a}}$ & $0.0980 \pm 0.0637$ & $0.00468 \pm 0.0051$ & $0.0108 \pm 0.0539$ & $\mathrm{n} / \mathrm{a}$ \\
$\mathrm{SOA}_{\text {total }}^{\mathrm{a}}$ & $0.239 \pm 0.149$ & $0.0715 \pm 0.0470$ & $0.147 \pm 0.124$ & $0.073 \pm 0.036$ \\
$\mathrm{Measured}^{\text {predicted }}{ }^{\mathrm{a}}$ & $4.49 \pm 2.80$ & $14.97 \pm 9.84$ & $7.303 \pm 6.20$ & $14.65 \pm 7.29$ \\
$\mathrm{SOA}_{\alpha \text {-pinene }}^{\mathrm{b}}$ & $0.537 \pm 0.349$ & $0.0541 \pm 0.0578$ & $0.612 \pm 0.30$ & $0.1181 \pm 0.0311$ \\
$\mathrm{SOA}_{\beta}^{\mathrm{b}}$-pinene & $0.178 \pm 0.116$ & $0.0090 \pm 0.0221$ & $0.0605 \pm 0.032$ & $\mathrm{n} / \mathrm{a}$ \\
$\mathrm{SOA}_{\text {Limonene }}^{\mathrm{b}}$ & $0.866 \pm 0.563$ & $0.041 \pm 0.0455$ & $0.0120 \pm 0.477$ & $\mathrm{n} / \mathrm{a}$ \\
$\mathrm{SOA}_{\text {total }}^{\mathrm{b}}$ & $1.64 \pm 1.06$ & $0.164 \pm 0.158$ & $0.744 \pm 0.842$ & $0.178 \pm 0.064$ \\
Measured/predicted $^{\mathrm{b}}$ & $0.65 \pm 0.42$ & $6.52 \pm 6.28$ & $1.438 \pm 1.63$ & $6.02 \pm 2.17$ \\
\hline
\end{tabular}

\footnotetext{
${ }^{\mathrm{a}}$ Indicates use of SOA yields extrapolated from Griffin et al. (1999a) i.e. $Y_{\alpha \text {-pinene }}=0.0102, Y_{\beta \text {-pinene }}=0.0034, Y_{\text {limonene }}=0.0082$

${ }^{\mathrm{b}}$ Indicates use of SOA yields scaled from i.e. $Y_{\alpha \text {-pinene }}=0.09, Y_{\beta \text {-pinene }}=0.030, Y_{\text {limonene }}=0.07$
}

represent $81 \%$ of monoterpene emissions on a global basis (Griffin et al., 1999b). Given that the monoterpene measurements by PTR-MS were mostly below detection limit, this contribution cannot be more accurately determined. Our best estimate from the calculations is likely to be from the Saxton et al. (2007) emissions data for the reasons discussed above; this predicts a total SOA concentration of $0.24 \pm 0.15 \mu \mathrm{g} \mathrm{m}^{-3}$ compared with the median observed value of $1.07 \pm 0.06 \mu \mathrm{g} \mathrm{m}^{-3}$. The measured $\mathrm{OM}$ will inevitably contain a small contribution from pre-existing $\mathrm{OM}$ into which the SOA partitions; an unknown contribution which is therefore not included in the calculation. Our calculations are likely to also under-represent the BSOA from isoprene and the monoterpenes for the reasons discussed above.

A more recent study (Shilling et al., 2008) suggests SOA yields from $\alpha$-pinene at low mass concentrations may be almost an order of magnitude higher ( $0.09 \mathrm{cf}$. 0.01 ) than yields extrapolated down from higher concentrations, as is routinely the case in modelling studies. It may be the case that yields from the other monoterpenes are similarly under represented by traditional extrapolation methods, so SOA estimates for the other terpenes are also provided by increasing the yields from Griffin et al. (1999a) in the same ratio as for the $\alpha$ pinene yields discussed above. Using these values gives a much better agreement between measured and predicted values (see Table 2). However, previous studies which compare modelled and measured OM (Heald et al., 2005; Johnson et al., 2006; De Gouw et al., 2005) did not have this recent yield data available to them.

\section{Discussion}

Organic aerosol mass loadings measured from an aircraft during AMMA provide the first regional measurements of organic particulate mass over clean forested regions of sub-tropical West Africa during the growing season. A median concentration of organic submicron aerosol mass $1.07 \mu \mathrm{g} \mathrm{m}^{-3}$ was observed. The measured values are comparable to previous measurements taken in tropical environments (e.g. $2.04 \pm 0.89 \mu \mathrm{g} \mathrm{m}^{-3}$ in Amazonia (Artaxo et al., 2002)). Although the concentrations measured in the African Sahel during the wet season reported in this paper are somewhat lower than those reported from Amazonia, this is reflected in lower VOC concentrations than are typical for Amazonia (2-5 ppb isoprene and more than $100 \mathrm{ppt} \alpha$ pinene have been reported (Karl et al., 2007; Greenberg et al., 2004)).

Global model estimates of $\mathrm{OM}$ in this region of West Africa derived from bulk yields and partitioning schemes cover the range $0 \mu \mathrm{g} \mathrm{m}^{-3}-3 \mu \mathrm{g} \mathrm{m}^{-3}$ (Chung and Seinfeld, 2002; Tsigaridis and Kanakidou, 2003; Lack et al., 2004). The Q-AMS derived regional organic mass loadings fall within the range of estimates from these global model 
simulations, and so appear to be in reasonable agreement, though as pointed out by Tsigaridis and Kanakidou (2003), SOA formation pathways and partitioning schemes in models are very uncertain. However, our bulk yield calculations of between $0.07-0.24 \mu \mathrm{g} \mathrm{m}^{-3}$ using the BAe-146 VOC data under predict the observed mass concentrations by a factor of 4.5-15. This result is similar to the analysis of Volkamer et al. (2006) who observed OA to be between 5-11 times greater than predicted OA using similar approaches and the same yield data as this study. These under predictions from studies in polluted mid-latitude environments correspond to photochemical ages of a few hours to a day i.e. for the likely range of ages sampled during AMMA, and although our estimates of SOA formation are somewhat uncertain, our range of estimates seems to under predict the measured OA to an extent roughly consistent with polluted environments. The global model results cited use similar approaches to those used in Volkamer et al. (2006) and this study, yet do not show such large underestimates. This points to further systematic differences between global model estimates and measurements of SOA, most likely caused by incorrect BVOC emission rates in global models. For example the uncertainty in emission estimates for isoprene and monoterpenes is thought to be a factor of three or higher (Guenther et al., 1995).

More recent yield data for $\alpha$-pinene obtained under atmospherically relevant conditions are much higher and show considerably better agreement between predictions and measurements (Shilling et al., 2008), particularly if the yields of the other monoterpenes are increased by the same proportion as the ratio between the new and old $\alpha$-pinene results (see Table 2). This highlights the large uncertainties associated with extrapolating yield data obtained at high mass concentrations and the need for yield data to be obtained under atmospherically relevant conditions for a much wider range of SOA precursor species.

Under prediction in both clean and polluted environments suggests that presence or absence of anthropogenic pollutants isn't the major factor affecting model accuracy, rather that the extrapolated yield data on which these predictions are based may be able to explain a significant fraction of the discrepancy. Inclusion of yields obtained under more atmospherically relevant conditions may be necessary if predictive models of OM are to be effective over a range of environments.

Acknowledgements. Based on a French initiative, AMMA was built by an international scientific group and is currently funded by a large number of agencies, especially from France, the UK, the US and Africa. It has been the beneficiary of a major financial contribution from the European Community's Sixth Framework Research Programme. Detailed information on scientific coordination and funding is available on the AMMA International web site http://www.amma-international.org. This work was funded by the EU and by the UK Natural Environment Research Council through the AMMA-UK Consortium grant and the National Centre for Atmospheric Science. The authors wish to acknowledge all the efforts of FAAM and the BAe-146 air and ground crews. G. Capes was supported by a NERC studentship NER/S/J/2004/13127. We wish to thank the anonymous reviewers of this manuscript for their valuable contributions.

Edited by: P. Formenti

\section{References}

Alfarra, M. R.: Insights into Atmospheric Organic Aerosols using an Aerosol Mass Spectrometer, PhD Thesis, Chemical Engineering, UMIST, Manchester, 2004.

Allan, J. D., Jimenez, J. L., Williams, P. I., Alfarra, M. R., Bower, K. N., Jayne, J. T., Coe, H., and Worsnop, D. R.: Quantitative sampling using an Aerodyne aerosol mass spectrometer - 1. Techniques of data interpretation and error analysis, J. Geophys. Res., 108, 4090, doi:10.1029/2002JD002358, 2003.

Allan, J. D., Bower, K. N., Coe, H., Boudries, H., Jayne, J. T., Canagaratna, M. R., Millet, D. B., Goldstein, A. H., Quinn, P. K., Weber, R. J., and Worsnop, D. R.: Submicron aerosol composition at Trinidad Head, California, during ITCT 2K2: Its relationship with gas phase volatile organic carbon and assessment of instrument performance, J. Geophys. Res., 109, D23S24, doi:10.1029/2003JD004208, 2004.

Andreae, M. O., Berresheim, H., Bingemer, H., Jacob, D. J., Lewis, B. L., Li, S. M., and Talbot, R. W.: The Atmospheric Sulfur Cycle over the Amazon Basin .2. Wet Season, J. Geophys. Res., 95, 16813-16824, 1990.

Andreae, M. O. and Crutzen, P. J.: Atmospheric aerosols: Biogeochemical sources and role in atmospheric chemistry, Science, 276, 1052-1058, 1997.

Artaxo, P., Martins, J. V., Yamasoe, M. A., Procopio, A. S., Pauliquevis, T. M., Andreae, M. O., Guyon, P., Gatti, L. V., and Leal, A. M. C.: Physical and chemical properties of aerosols in the wet and dry seasons in Rondonia, Amazonia, J. Geophys. Res., 107, 8081, doi:10.1029/2001JD000666, 2002.

Atkinson, R., Baulch, D. L., Cox, R. A., Crowley, J. N., Hampson, R. F., Hynes, R. G., Jenkin, M. E., Rossi, M. J., Troe, J., and IUPAC Subcommittee: Evaluated kinetic and photochemical data for atmospheric chemistry: Volume II - gas phase reactions of organic species, Atmos. Chem. Phys., 6, 3625-4055, 2006, http://www.atmos-chem-phys.net/6/3625/2006/.

Canagaratna, M. R., Jayne, J. T., Jimenez, J. L., Allan, J. D., Alfarra, M. R., Zhang, Q., Onasch, T. B., Drewnick, F., Coe, H., Middlebrook, A., Delia, A., Williams, L. R., Trimborn, A. M., Northway, M. J., DeCarlo, P. F., Kolb, C. E., Davidovits, P., and Worsnop, D. R.: Chemical and microphysical characterization of ambient aerosols with the aerodyne aerosol mass spectrometer, Mass Spectrom. Rev., 26, 185-222, 2007.

Chung, S. H. and Seinfeld, J. H.: Global distribution and climate forcing of carbonaceous aerosols, J. Geophys. Res., 107, 4407, doi:10.1029/2001JD001397, 2002.

Claeys, M., Graham, B., Vas, G., Wang, W., Vermeylen, R., Pashynska, V., Cafmeyer, J., Guyon, P., Andreae, M. O., Artaxo, P., and Maenhaut, W.: Formation of secondary organic aerosols through photooxidation of isoprene, Science, 303, 1173-1176, 2004.

Crosier, J., Allan, J. D., Coe, H., Bower, K. N., Formenti, P., and Williams, P. I.: Chemical composition of summertime aerosol in 
the Po Valley (Italy), northern Adriatic and Black Sea, Q. J. Roy. Meteorol. Soc., 133, 61-75, 2007.

De Gouw, J. A., Middlebrook, A. M., Warneke, C., Goldan, P. D., Kuster, W. C., Roberts, J. M., Fehsenfeld, F. C., Worsnop, D. R., Canagaratna, M. R., Pszenny, A. A. P., Keene, W. C., Marchewka, M., Bertman, S. B., and Bates, T. S.: Budget of organic carbon in a polluted atmosphere: Results from the New England Air Quality Study in 2002, J. Geophys. Res., 110, 305, doi:10.1029/2004JD005623, 2005.

Dommen, J., Metzger, A., Duplissy, J., Kalberer, M., Alfarra, M. R., Gascho, A., Weingartner, E., Prevot, A. S. H., Verheggen, B., and Baltensperger, U.: Laboratory observation of oligomers in the aerosol from isoprene/ $\mathrm{NO}_{\mathrm{x}}$ photooxidation, Geophys. Res. Lett., 33, L13805, doi:10.1029/2006GL026523, 2006.

Drewnick, F., Hings, S. S., DeCarlo, P., Jayne, J. T., Gonin, M., Fuhrer, K., Weimer, S., Jimenez, J. L., Demerjian, K. L., Borrmann, S., and Worsnop, D. R.: A new time-of-flight aerosol mass spectrometer (TOF-AMS) - Instrument description and first field deployment, Aerosol Science and Technology, 39, 637$658,2005$.

Fenger, J.: Urban air quality, Atmos. Environ., 33, 4877-4900, 1999.

Fowler, D., Coyle, M., Anderson, R., Ashmore, M. R., Bower, J. S., Burgess, R. A., Cape, J. N., Cox, R. A., Derwent, R. G., Dollard, G. J., Grennfelt, P., Harrison, R. M., Hewitt, C. N., Hov, O., Jenkin, M. E., Lee, D. S., Maynard, R. L., Penkett, S. A., Smith, R. I., Stedman, J. R., Weston, K. J., Williams, M. L., and Woods, P. J.: Ozone in the United Kingdom, Department of the Environment, Transport and the Regions, ISBN 1870393309 , 1997.

Greenberg, J., Guenther, A., Petron, G., Wiedinmyer, C., Vega, O., Gatti, L. V., Tota, J., and Fisch, G.: Biogenic VOC emissions from forested Amazonian landscapes, Global Change Biol., 10, 651-666, 2004.

Griffin, R. J., Cocker, D. R., Flagan, R. C., and Seinfeld, J. H.: Organic aerosol formation from the oxidation of biogenic hydrocarbons, J. Geophys. Res., 104, 3555-3567, 1999a.

Griffin, R. J., Cocker, D. R., Seinfeld, J. H., and Dabdub, D.: Estimate of global atmospheric organic aerosol from oxidation of biogenic hydrocarbons, Geophys. Res. Lett., 26, 2721-2724, 1999b.

Guenther, A., Hewitt, C. N., Erickson, D., Fall, R., Geron, C., Graedel, T., Harley, P., Klinger, L., Lerdau, M., Mckay, W. A., Pierce, T., Scholes, B., Steinbrecher, R., Tallamraju, R., Taylor, J., and Zimmerman, P.: A Global-Model of Natural Volatile Organic-Compound Emissions, J. Geophys. Res., 100, 8873$8892,1995$.

Guenther, A., Otter, L., Zimmerman, P., Greenberg, J., Scholes, R., and Scholes, M.: Biogenic hydrocarbon emissions from southern African savannas, J. Geophys. Res., 101, 25859-25865, 1996.

Guenther, A., Geron, C., Pierce, T., Lamb, B., Harley, P., and Fall, R.: Natural emissions of non-methane volatile organic compounds; carbon monoxide, and oxides of nitrogen from North America, Atmos. Environ., 34, 2205-2230, 2000.

Heald, C. L., Jacob, D. J., Park, R. J., Russell, L. M., Huebert, B. J., Seinfeld, J. H., Liao, H., and Weber, R. J.: A large organic aerosol source in the free troposphere missing from current models, Geophys. Res. Lett., 32, L18809, doi:10.1029/2005GL023831, 2005.
Hopkins, J. R., Lewis, A. C., and Read, K. A.: A two-column method for long-term monitoring of non-methane hydrocarbons (NMHCs) and oxygenated volatile organic compounds (oVOCs), J. Environ. Monitor., 5, 8-13, 2003.

Janicot, S., Thorncroft, C. D., Ali, A., Asencio, N., Berry, G., Bock, O., Bourles, B., Caniaux, G., Chauvin, F., Deme, A., Kergoat, L., Lafore, J.-P., Lavaysse, C., Lebel, T., Marticorena, B., Mounier, F., Nedelec, P., Redelsperger, J.-L., Ravegnani, F., Reeves, C. E., Roca, R., de Rosnay, P., Schlager, H., Sultan, B., Tomasini, M., Ulanovsky, A., and ACMAD forecasters team: Large-scale overview of the summer monsoon over West Africa during the AMMA field experiment in 2006, Ann. Geophys., 26, 25692595, 2008, http://www.ann-geophys.net/26/2569/2008/.

Jayne, J. T., Leard, D. C., Zhang, X. F., Davidovits, P., Smith, K. A., Kolb, C. E., and Worsnop, D. R.: Development of an aerosol mass spectrometer for size and composition analysis of submicron particles, Aerosol Sci. Technol., 33, 49-70, 2000.

Jimenez, J. L., Jayne, J. T., Shi, Q., Kolb, C. E., Worsnop, D. R., Yourshaw, I., Seinfeld, J. H., Flagan, R. C., Zhang, X. F., Smith, K. A., Morris, J. W., and Davidovits, P.: Ambient aerosol sampling using the Aerodyne Aerosol Mass Spectrometer, J. Geophys. Res., 108, 8425, doi:10.1029/2001JD001213, 2003.

Johnson, D., Utembe, S. R., Jenkin, M. E., Derwent, R. G., Hayman, G. D., Alfarra, M. R., Coe, H., and McFiggans, G.: Simulating regional scale secondary organic aerosol formation during the TORCH 2003 campaign in the southern UK, Atmos. Chem. Phys., 6, 403-418, 2006, http://www.atmos-chem-phys.net/6/403/2006/.

Kanakidou, M., Seinfeld, J. H., Pandis, S. N., Barnes, I., Dentener, F. J., Facchini, M. C., Van Dingenen, R., Ervens, B., Nenes, A., Nielsen, C. J., Swietlicki, E., Putaud, J. P., Balkanski, Y., Fuzzi, S., Horth, J., Moortgat, G. K., Winterhalter, R., Myhre, C. E. L., Tsigaridis, K., Vignati, E., Stephanou, E. G., and Wilson, J.: Organic aerosol and global climate modelling: a review, Atmos. Chem. Phys., 5, 1053-1123, 2005, http://www.atmos-chem-phys.net/5/1053/2005/.

Karl, T., Guenther, A., Yokelson, R. J., Greenberg, J., Potosnak, M., Blake, D. R., and Artaxo, P.: The tropical forest and fire emissions experiment: Emission, chemistry, and transport of biogenic volatile organic compounds in the lower atmosphere over Amazonia, J. Geophys. Res., 112, D18302, doi:10.1029/2007JD008539, 2007.

Kavouras, I. G., Mihalopoulos, N., and Stephanou, E. G.: Formation of atmospheric particles from organic acids produced by forests, Nature, 395, 683-686, 1998.

Kavouras, I. G., Mihalopoulos, N., and Stephanou, E. G.: Formation of biogenic secondary organic aerosol, J. Aerosol Sci., 31, 172-173, 2000.

Kesselmeier, J., Kuhn, U., Wolf, A., Andreae, M. O., Ciccioli, P., Brancaleoni, E., Frattoni, M., Guenther, A., Greenberg, J., Vasconcellos, P. D., de Oliva, T., Tavares, T., and Artaxo, P.: Atmospheric volatile organic compounds (VOC) at a remote tropical forest site in central Amazonia, Atmos. Environ., 34, 4063-4072, 2000.

Kroll, J. H., Ng, N. L., Murphy, S. M., Flagan, R. C., and Seinfeld, J. H.: Secondary organic aerosol formation from isoprene photooxidation, Environ. Sci. Technol., 40, 1869-1877, 2006.

Kuhn, U., Rottenberger, S., Biesenthal, T., Wolf, A., Schebeske, G., Ciccioli, P., Brancaleoni, E., Frattoni, M., Tavares, T. M., and 
Kesselmeier, J.: Isoprene and monoterpene emissions of Amazonian tree species during the wet season: Direct and indirect investigations on controlling environmental functions, J. Geophys. Res., 107, 8071, doi:10.1029/2001JD000978, 2002.

Kulmala, M., Hameri, K., Aalto, P. P., Makela, J. M., Pirjola, L., Nilsson, E. D., Buzorius, G., Rannik, U., Dal Maso, M., Seidl, W., Hoffman, T., Janson, R., Hansson, H. C., Viisanen, Y., Laaksonen, A., and O'Dowd, C. D.: Overview of the international project on biogenic aerosol formation in the boreal forest (BIOFOR), Tellus Series B-Chemical and Physical Meteorology, 53, 324-343, 2001.

Lack, D. A., Tie, X. X., Bofinger, N. D., Wiegand, A. N., and Madronich, S.: Seasonal variability of secondary organic aerosol: A global modeling study, J. Geophys. Res., 109, D03203, doi:10.1029/2003JD003418, 2004.

Lim, Y. B. and Ziemann, P. J.: Products and Mechanism of Secondary Organic Aerosol Formation from Reactions of n-Alkanes with OH Radicals in the Presence of NOx, Environ. Sci. Technol., 39, 9229-9236, doi:10.1021/es051447g, 2005.

Matthew, B. M., Middlebrook, A. M., and Onasch, T. B.: Collection Efficiencies in an Aerodyne Aerosol Mass Spectrometer as a Function of Particle Phase for Laboratory Generated Aerosols, Aerosol Sci. Technol., 42, 884-898, 2008.

Otter, L. B., Guenther, A., and Greenberg, J.: Seasonal and spatial variations in biogenic hydrocarbon emissions from southern African savannas and woodlands, Atmos. Environ., 36, 42654275, 2002.

Parker, D. J., Burton, R. R., Diongue-Niang, A., Ellis, R. J., Felton, M., Taylor, C. M., Thorncroft, C. D., Bessemoulin, P., and Tompkins, A. M.: The diurnal cycle of the West African monsoon circulation, Q. J. Roy. Meteorol. Soc., 131, 2839-2860, 2005a.

Parker, D. J., Thorncroft, C. D., Burton, R. R., and Diongue-Niang, A.: Analysis of the African easterly jet, using aircraft observations from the JET2000 experiment, Q. J. Roy. Meteor. Soc., 131, 1461-1482, 2005b.

Rappengluck, B., Oyola, P., Olaeta, I., and Fabian, P.: The evolution of photochemical smog in the Metropolitan Area of Santiago de Chile, J. Appl. Meteorol., 39, 275-290, 2000.

Rissler, J., Swietlicki, E., Zhou, J., Roberts, G., Andreae, M. O., Gatti, L. V., and Artaxo, P.: Physical properties of the submicrometer aerosol over the Amazon rain forest during the wetto-dry season transition - comparison of modeled and measured CCN concentrations, Atmos. Chem. Phys., 4, 2119-2143, 2004, http://www.atmos-chem-phys.net/4/2119/2004/.

Robinson, A. L., Donahue, N. M., Shrivastava, M. K., Weitkamp, E. A., Sage, A. M., Grieshop, A. P., Lane, T. E., Pierce, J. R., and Pandis, S. N.: Rethinking organic aerosols: Semivolatile emissions and photochemical aging, Science, 315, 1259-1262, 2007.

Ruppert, L. and Becker, K. H.: A product study of the $\mathrm{OH}$ radicalinitiated oxidation of isoprene: formation of C-5-unsaturated diols, Atmos. Environ., 34, 1529-1542, 2000.

Saxton, J. E., Lewis, A. C., Kettlewell, J. H., Ozel, M. Z., Gogus, F., Boni, Y., Korogone, S. O. U., and Serça, D.: Isoprene and monoterpene measurements in a secondary forest in northern Benin, Atmos. Chem. Phys., 7, 4095-4106, 2007, http://www.atmos-chem-phys.net/7/4095/2007/.
Shilling, J. E., Chen, Q., King, S. M., Rosenoern, T., Kroll, J. H., Worsnop, D. R., McKinney, K. A., and Martin, S. T.: Particle mass yield in secondary organic aerosol formed by the dark ozonolysis of ?-pinene, Atmos. Chem. Phys., 8, 2073-2088, 2008, http://www.atmos-chem-phys.net/8/2073/2008/.

Spivakovsky, C. M., Yevich, R., Logan, J. A., Wofsy, S. C., Mcelroy, M. B., and Prather, M. J.: Tropospheric Oh in a 3Dimensional Chemical Tracer Model - an Assessment Based on Observations of Ch3ccl3, J. Geophys. Res., 95, 18441-18471, 1990.

Steinbacher, M., Dommen, J., Ordonez, C., Reimann, S., Gruebler, F. C., Staehelin, J., and Prevot, A. S. H.: Volatile organic compounds in the Po Basin. part A: Anthropogenic VOCs, J. Atmos. Chem., 51, 271-291, 2005.

Tsigaridis, K. and Kanakidou, M.: Global modelling of secondary organic aerosol in the troposphere: a sensitivity analysis, Atmos. Chem. Phys., 3, 1849-1869, 2003, http://www.atmos-chem-phys.net/3/1849/2003/.

Volkamer, R., Jimenez, J. L., San Martini, F., Dzepina, K., Zhang, Q., Salcedo, D., Molina, L. T., Worsnop, D. R., and Molina, M. J.: Secondary organic aerosol formation from anthropogenic air pollution: Rapid and higher than expected, Geophys. Res. Lett., 33, L17811, doi:10.1029/2006GL026899, 2006.

White, M. L., Russo, R. S., Zhou, Y., Ambrose, J. L., Haase, K., Frinak, E. K., Varner, R. K., Wingenter, O. W., Mao, H., Talbot, R., and Sive, B. C.: Are biogenic emissions a significant source of summertime atmospheric toluene in the rural Northeastern United States?, Atmos. Chem. Phys., 9, 81-92, 2009, http://www.atmos-chem-phys.net/9/81/2009/.

Zhang, Q., Canagaratna, M. R., Jayne, J. T., Worsnop, D. R., and Jimenez, J. L.: Time- and size-resolved chemical composition of submicron particles in Pittsburgh: Implications for aerosol sources and processes, J. Geophys. Res., 110, D07S09, doi:10.1029/2004JD004649, 2005.

Zhang, Q., Jimenez, J. L., Canagaratna, M. R., Allan, J. D., Coe, H., Ulbrich, I., Alfarra, M. R., Takami, A., Middlebrook, A. M., Sun, Y. L., Dzepina, K., Dunlea, E., Docherty, K., DeCarlo, P. F., Salcedo, D., Onasch, T., Jayne, J. T., Miyoshi, T., Shimono, A., Hatakeyama, S., Takegawa, N., Kondo, Y., Schneider, J., Drewnick, F., Borrmann, S.,Weimer, S., Demerjian, K., Williams, P., Bower, K., Bahreini, R., Cottrell, L., Griffin, R. J., Rautiainen, J., Sun, J. Y., Zhang, Y. M., and Worsnop, D. R.: Ubiquity and dominance of oxygenated species in organic aerosols in anthropogenically-influenced Northern Hemisphere midlatitudes, Geophys. Res. Lett., 34, L13801, doi:10.1029/2007GL029979, 2007.

Zhou, J. C., Swietlicki, E., Hansson, H. C., and Artaxo, P.: Submicrometer aerosol particle size distribution and hygroscopic growth measured in the Amazon rain forest during the wet season, J. Geophys. Res., 107, 8055, doi:10.1029/2000JD000203, 2002. 